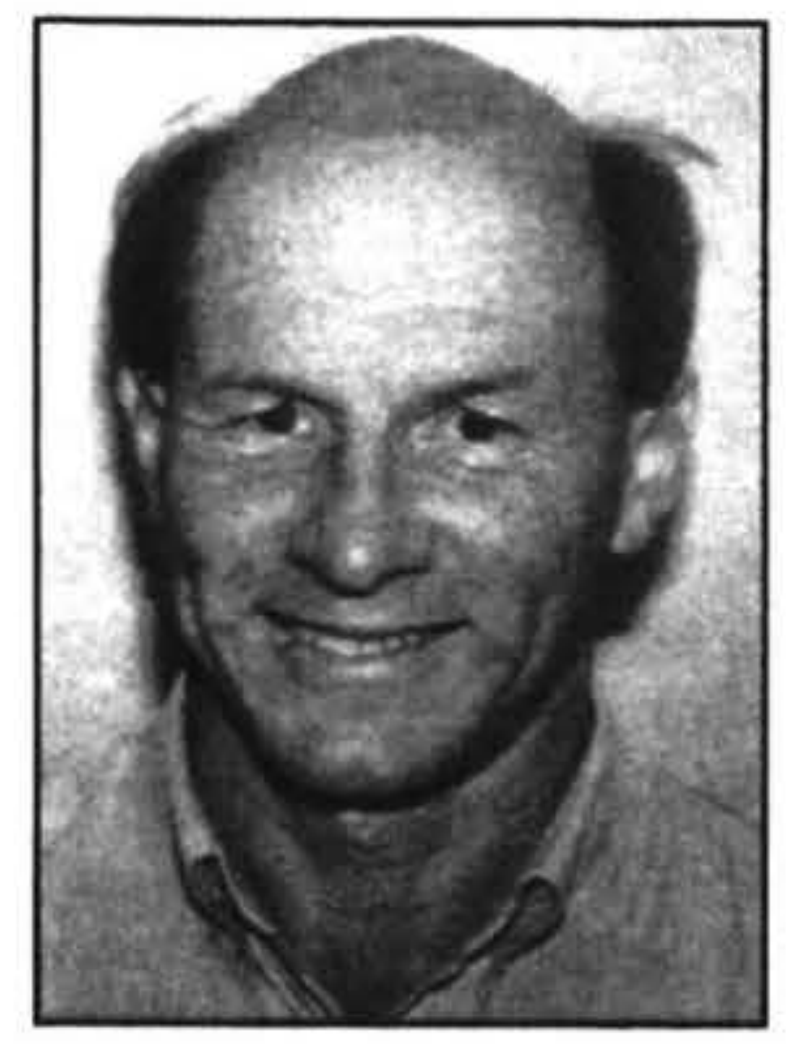

\title{
LOCAL AUTHORITY RESPONSES TO UNEMPLOYMENT
}

\author{
Sean Bevin \\ Napier City Council
}

\begin{abstract}
This paper examines the initiatives that local authorities in New Zealand have taken since the late 1970s to facilitate the economic development and employment creation in their districts. The paper examines why local autorities have become involved in both issues, the variation across them in both level and range of initiatives, and levels of effectiveness. Several case studies will highlight a number of the opportunitites as well as the difficulties involved. The paper concludes that whilst local authorities have attempted to play a constructive and responsible role, there are still a number of unresolved issues concerning their role in local economic development. This paper argues that local authorities should be involved and have the ability to develop and implement programmes to address local employment issues.
\end{abstract}

This paper examines the different initiatives that have been put in place over the past 15 years or so by local authorities in New Zealand, to address employment issues at the local level.

In particular, the paper provides a brief history of Local Government involvement in employment matters, addresses why local authorities have become involved and indicates the varying levels of involvement and identifies the different types of employment initiatives that have been put in place by local Councils. Five case studies of individual Council employment initiatives are then reviewed.

\section{History}

The direct involvement of local authorities in local employment issues has its origins in the late 1970s when Central Government began to introduce a range of job creation programmes to address the growing unemployment problem in New Zealand. A good example of such a programme was the PEP programme. Many local authorities in the country became involved in this scheme and a number of valuable community projects were undertaken through it. At the same time, may of those working under the programme gained valuable job experience and skills for future permanent employment. With this and other job creation programmes that they were involved in, local authorities provided considerable funding, materials and work opportunities.

Unfortunately, this was not always acknowledged by Central Government in the mid 1980's when, with the advent of deregulation, job creation programmes began to be phased out. In the process, local authorities, without any real justification, were criticised by Central Government for using job creation programmes to replace permanent staff. Research undertaken at the time by the New Zealand Local Government Association indicated that at the same time as Council's took on more staff under the various job creation schemes, their permanent workforces actually increased.

In the early 1980s, several of Regional Councils began formulating regional economic development strategies as part of their regional planning schemes. In some cases the strategies included reference to promoting and facilitating economic development initiatives, indirectly through a regional economic development process. At the same time, local authorities in New Zealand, particularly in the larger metropolitan centres, became more actively involved in direct local employment creation initiatives, for example, the Wellington City Council's new venture units in Central Wellington. This process intensified from the mid-1980s with the onset of Government deregulation policies and economic restructuring, which began to have marked negative impacts at the local/regional levels, such as increasing unemployment and factory classes.

At the same time, local authorities increasingly came to realise that with or without the support of Central Government, they had an important role to play in facilitating and assisting employment creation at the local level. With the decrease in direct Central Government involvement in employment creation initiatives and regional development policies, it was often left to local authorities, as the natural 'leaders' of local communities, to galvanise local actions to address local employment issues.

Today, most, local Councils in New Zealand, are directly or indirectly involved in a number of ways, in assisting local employment efforts in their communities, often in partnership with Central Government agencies, such as NZES, 


\section{Basis for involvement}

There are a number of reasons why Local Government in New Zealand has become more actively involved in recent years in local employment issues. These reasons include:

* Following Central Government request for local authority participation in job creation programmes such as those run through the Department of Labour (NZES and CEG).

* The need for positive local action in response to the adverse local impacts of Central Government restructuring policies, economic downturn and negative local economic changes (e.g. freezing works closures and adverse climatic events).

* Through its important advocacy, networking and resources provision responsibilities, Local Government is well-placed to make a significant contribution to addressing local employment issues.

* Major local community concerns over the adverse economic and social impacts of unemployment. This factor is often cited as a major community problem to be addressed, in annual ratepayer opinion surveys undertaken by local authorities.

* The oft-mentioned principle of 'providing local solution to local problems' provides a sound basis for the involvement of local authorities in local employment issues.

\section{Degree of involvement}

In addressing local employment issues, local authorities adopt an approach along a continuum, ranging from a basic minimalist involvement to a proactive one. Local authorities can decide to either start at the beginning of the continuum and move along it, depending on the local need or the effectiveness of their earlier initiatives, or enter the continuum at a later stage eg a pro-active approach. The level of entry to the continuum should, however, be based on a comprehensive assessment of the employment conditions of the local economy and the availability of resources to support local employment initiatives, and should have the support of the local community.

This continuum of local authority involvement in the local employment arena, is indicated in the diagram on the next page.

\section{Range of employment initiatives}

Over the years, local authorities have implemented a wide range of initiatives to address their local employment circumstances, either directly or indirectly (through the local economic development process). Each local authority's particular set of actions will of course be influenced by such factors as political choice, resource availability and the local employment situation. Amidst the wide range of local
Involvement in Central Government employment - creation programmes, such as those operated by NZES and the Community Employment Group.

Involvement in community-based employment responses. For example, the provision of funding, administrative support and management input to Community Work Trusts, Employment Resource Centres and other similar agencies.

Establishment of 'home grown' local authority employment schemes, such as the Christchurch City Council's 'Youth Employment Scheme', Nelson City Council's 'Work Voucher Scheme' and the Hamilton City Council's 'Employment Initiatives Unit'.

Indirect economic development initiatives to increase local employment levels. Examples of such initiatives include the 'Be Your Own Boss' and 'Business Grow' programmes, general business facilitation, business mentoring, investment attraction and tourism promotion.

Economic planning, aimed essentially at assisting local business to improve their business prospects and, hence, market and employment development. For example, local economic monitoring, local area marketing information and the provision of data bases of products and services.

\section{Case studies}

This section offers case study examples of different local authority employment practices:

\section{Napier City Council}

Two particular examples here are the Council's 'Be Your Own Boss' and 'Business Grow' programmes. Both programmes are part funded by the Community Employment Group of the Department of Labour and delivered through the Council's Enterprise Unit. The first programme aims to assist unemployed people into their own small businesses by providing an extensive support system, from the initiation of a new business idea right through to the ongoing monitoring of a firm's actual operation.

The Council's 'Business Grow' programme provides an advisory and referral service for business in the Hawke's Bay area. The Council's 'Business Grow' co-ordinator visits a specified number of businesses in the region each week, to introduce them to the range of Council business support services, discusses their performance generally, identify any problem areas and refers them, if necessary, to appropriate professional advisory agencies in the local area. Along with company restructuring and a facilitative problem-solving approach, the Enterprise Unit provides a comprehensive policy of services for small business and self-employment development.

\section{Christchurch City Council}


This Council has been involved in recent years in three specific youth-related employment initiatives, namely:-

a) A "Youth Employment Service", which provides a central physical place in the City from which employment information, advice and referral services are available.

b) Youth employment projects aimed at improving the chances of young job-seekers obtaining paid employment. The projects include job clubs and job-seeker programmes, marae-based programmes, enterprise-training and self-employment for young people, and group training programmes within specific industry sectors.

c) Job skills development through fully subsidised, 30 hour a week, 26 weeks - long work/training programmes.

\section{Nelson City Council}

Under the Council's "Work Voucher Scheme", a so-called Work Voucher Trust acts as an intermediary between jobseekers and job-providers, in ensuring the successful completion of casual work projects. A prospective work provider purchases a "Work Voucher" from the Council's Cashier Department, at a standard rate of $\$ 10.00$ per hour. The provider is required to provide details of the task to be done and the hours of work required to complete it. The scheme administrator then has the responsibility of matching an unemployed job-seeker to the job specifications.

\section{Hamilton City Council}

The Hamilton City Council's Employment Initiatives Unit has a $\$ 200,000$ plus NZES contract to provide back-to-work training for local long-term unemployed people. The programme involves the provision of a number of five-day Job Action workshops, aimed at ensuring that the job-seekers involved are able to communicate effectively, are sufficiently motivated and ready to seek work, have self-confidence and know where to ask for support, if necessary. The Hamilton City Council runs Community Taskforce and Taskforce Green programmes.

\section{Wellington City Council}

The Capital Development Agency of the Wellington City Council provides a number of policies to directly or indirectly assist employment development in the City. The policies include:-

* The long-established 'New Venture Factory' programme for new small business start-ups.

* The provision of an 'Employment Advisor' to inform Council managers of the range of Government employment schemes available for project work.

* The provision of a business advisory and training service. This includes the 'Business Grow' programme and 'Business Mentor' scheme.

* Business development assistance initiatives, such as facilitating overseas investment into the $\mathrm{City}$, co-ordination of industry action groups to address specific development barriers within them, new business investment migrant assistance and the preparation of business opportunity directories.

\section{Table 1. Local Authority economic and employment development roles}

Basic
Minimalist

Medium

Active

Pro-active
General awareness of local economic and employment changes.

Limited political advocacy

Some economic and employment information provision

District Plan policies

Act on strategic local economic and employment issues.

LA recognises need to play an appropriate role in the LED and employment process May provide a specialist resource within the Council, to facilitate/assist the process. Economic advocacy/strategic economic and employment issues are important. Utilises Government employment programmes

Provides a range of local economic and employment monitoring information.

LA strongly committed to assisting in facilitating local economic and employment development.

Involved in the establishment and funding of a, usually outside, economic development agency.

Limited economic information, advisory and monitoring service.

Some involvement in Government enterprise and employment programmes.

Economic development "colours" much of a local authoritys work.

Vision/mission statements also reflect this

LA takes an unashamed "lead" role in facilitating local economic and employment development. Strong political leadership

Active Enterprise Unit or Agency

Regular monitoring of local economy 
From the above, it can be seen that some local authorities in New Zealand have implemented a range of sometimes quite novel and targeted employment creation initiatives, based on their perception of the major employment and related issues prevailing within their communities. Obviously, the involvement of Councils in the employment field has varied from a relatively low level involvement in Central Government employment programmes, to a more comprehensive approach, involving, in the case of a number of authorities, both a strong direct employment creation approach and a supportive local economic/business development-based policy.

\section{Policy effectiveness}

Many local authorities in New Zealand have now had a lengthy period of involvement in employment-creation initiatives at the local level. In the process, a number of them have moved on considerably from a narrow focus on direct employment creation policies (eg participation in Central Government employment programmes) to a broader approach of facilitating employment-creation through a strong local economic development effort. At the same time, they have increased their level of expertise in this area which has, in turn, increased the overall effectiveness of their various employment initiatives. This can be assessed by looking at the outcomes of some of the programmes in which they have been involved. For example the 'Be Your Own Boss' new small business development programme in Napier, has $82 \%$ of new businesses established under the programme still in existence after five years. $60 \%$ of the businesses are soletraders and the rest partnerships, usually with a spouse.

The NZES Enterprise Allowance assists with small business start-ups. In Napier, $84 \%$ of people involved with the allowance have established their new businesses using the scheme.

The 'Business Grow' industry visitation programme in Napier lead to $25-30 \%$ of visits result in referrals for professional help. Hopefully, correction of business problems will prove positive for industry activity and employment in the future.

The Christchurch City Council's Youth Employment 'Job Skills' programme has seen some 2500 young people come through the scheme since it began in 1993. The Council has moved on to a more intensive 1:1 support programme with young job seekers in Christchurch, in assisting them into paid permanent employment.

A 1995 New Zealand Local Government Association submission to the Government Employment Taskforce commented that some 150 people had joined the Nelson City Council's Work Voucher Scheme since it got underway in July 1993. Those joining the scheme were either unemployed or did not have full time work. Around $90 \%$ of scheme users were commercial enterprises.

Wellington City Council programmes. The Council's Capital Development Agency provides small business advice to some 1200 people annually and, of these $50 \%$ actually establish a business and $70 \%$ are still trading 12 months later. Over the 1995/96 year, the Agency's 'Business Grow 'staff visited 2000 businesses, of which 226 were referred to the Local Business Development board for possible grants. The Agency's first Business Opportunities Directory resulted in seven Wellington companies being matched with investors, with a potential total investment port folio of $\$ 1.5 \mathrm{~m}$. Some 100 businesses are currently being mentored, under the Agency's Business Mentor programme. Currently, the Wellington City Council's venture factories around the City are the base for some 40 businesses employing around 170 people. The Council's involvement in job creation programmes run in conjunction with NZES, has been positive and some of the programme workers have been placed into permanent Council employment as a result.

The Hamilton City Council's 'Employment Initiatives Unit', which has been operating for some six years now, is currently achieving a permanent employment placement rate of over $60 \%$. Currently, some 160 people are involved with the Council's programmes. The programmes have achieved the highest placement rate in New Zealand and the largest move of benefit recipients into employment, and are regarded as a New Zealand model for the involvement of Councils in direct employment creation initiatives.

\section{Future concerns}

Looking to the future, there are a number of matters concerning the role of local authorities in employment which, if addressed adequately, would assist materially in their efforts in this field.

At the Central Government/National levels there are inflexibilities associated with the administration and operation of some employment programmes. Local authorities perceive a lack of true appreciation of the past work , performance, and competence of local authorities in the employment field.

There is a chronic funding shortage and lack of continuity of funding as well as a lack of real autonomy for local agencies in expending Central Government funds on local initiatives.

There is a lack of a legislative underpinning for the involvement of local authorities in local economic development and a perceived insensitivity of employment policy to regional variations in both labour market performance and local economic bases.

These concerns are accompanies by a strong lobby against 'government' involvement in economic development and employment issues by the Business Round Table for example which makes it difficult to persuade some committees in most local authories of the local benefits of such expenditures.

In some instances, there is a perceived lack of commitment to a strong partnership approach between Central Government and local communities, in addressing local employment issues and an over-emphasis in Government employ- 
ment policy on the needs of the long-term unemployed.

At the local level, the employment work of local Councils and other local agencies is often hindered by misconceptions also of their role in local economic development and employment creation, and the close connection between the general City/District development work of local authorities and their efforts to promote and facilitate business and employment development.

\section{Future research}

The future employment development work of local authorities in New Zealand could also be assisted significantly by research and investigation into a number of related subject areas, such as the impacts on regional and local economic/ employment performance of Central Government macro and micro economic policies.

There is need for a theoretical underpinning to state assistance for the development of regional and local economies.

There is a real need for a comprehensive assessment of the effectiveness of past local community policies in New Zealand, to promote and facilitate local economic development and employment creation.

Finally there is a need to research appropriate future local strategies and policies to develop local economies in New Zealand and their employment bases.

\section{Author}

Sean Bevin is an economist with theCity of Napier, PO Box 6010 , Napier. 